\title{
Anaerobic Biodegradation of Raw and Pre-treated Brewery Spent Grain Utilizing Solid State Anaerobic Digestion
}

\author{
Mario Panjičko, ${ }^{1, *}$ Gregor Drago Zupančič ${ }^{2}$ and Bruno Zelićc \\ ${ }^{1}$ Brodarski Institute, Environmental Technologies Center, Av. V. Holjevca 20, HR-10020 Zagreb, Croatia \\ ${ }^{2}$ University of Nova Gorica, School of Environmental Sciences, Vipavska c. 13, SI-5000 Nova Gorica \\ ${ }^{3}$ University of Zagreb, Faculty of Chemical Engineering and Technology, Marulićev trg 19, HR-10000 Zagreb \\ * Corresponding author: E-mail: mario.panjicko@gmail.com \\ tel/fax: 00385911515152
}

Received: 16-03-2015

\begin{abstract}
The brewery spent grain (BSG) represents approximately $85 \%$ of the total quantity of by-products from the brewing industry. The biogas production from the BSG has been the subject of several studies in recent years, due to relatively high energy consumption in the brewing process and due to the increasing energy costs. The biodegradability of raw and pretreated BSG in a single-stage and two-stage solid-state anaerobic digestion (SS-AD) system was determined in this study. The results showed a biogas potential of $120 \mathrm{~L} \mathrm{~kg}^{-1}$ of wet BSG. In the single-stage system, the biogas yield obtained from raw BSG $\left(87.4 \mathrm{~L} \mathrm{~kg}^{-1}\right)$ was almost equal to the yield obtained from the pre-treated BSG $\left(89.1 \mathrm{~L} \mathrm{~kg}^{-1}\right)$, while the methane yield was 51.9 and $55.3 \mathrm{~L} \mathrm{~kg}^{-1}$ and the biodegradation was $62.0 \%$ and $62.2 \%$ for raw and pre-treated BSG, respectively. In two-stage SS-AD the pre-treated BSG showed better results, with the biogas yield of $103.2 \mathrm{~L} \mathrm{~kg}^{-1}$ and the biodegradation of $73.6 \%$, while the biogas yield obtained from raw BSG was $89.1 \mathrm{~L} \mathrm{~kg}^{-1}$, with the biodegradation of $63.5 \%$. In two-stage process the obtained methane yields from raw and pre-treated BSG were identical $\left(58.7 \mathrm{~L} \mathrm{~kg}^{-1}\right)$.
\end{abstract}

Keywords: Acid pre-treatment, biogas, brewery spent grain, solid-state anaerobic digestion

\section{Introduction}

The brewing industry generates relatively large amounts of by-products and waste, such as brewery wastewater, surplus yeast and brewery spent grain (BSG). The utilization of surplus yeast and BSG in a form of animal fodder or other secondary resources is well known. ${ }^{1}$ However, with increasing energy costs, the brewing industry, which consumes approx. 20-40 L of natural gas per $\mathrm{L}$ of brew, strives to convert most of its waste to alternative energy sources. In such perspective, the anaerobic digestion has become an important part of the brewing industry for supplying renewable energy - biogas, produced from the above mentioned waste substrates. In the recent years, the treatment process of the brewing wastewater has been thoroughly studied and well developed., ${ }^{2,3}$ Predominantly, the granular sludge blanket technology, such as UASB (up-flow anaerobic sludge blanket) reactor has been applied in this field. ${ }^{4}$ Surplus yeast has also been successfully utilised as a bioenergy resource. ${ }^{5,6}$ The most promising substrate for biogas production is the BSG, due to its large quantity (approx. $17 \mathrm{~kg}$ per hectolitre of brew). However, a successful and sustainable industrial process has not yet been developed due to its low biodegradability. BSG contains about $16.8-25.4 \%$ cellulose, $21.8-28.4 \%$ hemicellulose and $11.9-27.8 \%$ of lignin. ${ }^{7}$ The major parts of the BSG constitute the kernel husk, pericarp and seed coat, which are rich in cellulose, non-cellulosic polysaccharides, lignin and proteins. In general, the BSG is considered a lignocellulosic material rich in fibres and proteins, which account for about $70 \%$ and $20 \%$ of its composition, respectively. However, the structural complexity of lignin, its high molecular mass, chemical stability and insolubility make the biodegradation of this lignocellulosic substrate quite difficult. Lignin is a cross-linked polymer of phenolic compounds, having a very complex molecular structure. It is present in plant primary cell walls, imparting structural support, non-permeability, and resistance against microbial attack. ${ }^{8}$ Lignin is biodegradable in an aerobic process and can get slowly degraded under anae- 
robic conditions as well. ${ }^{9}$ One of the possible solutions to enhance the anaerobic digestion of lignocellulosic biomass is the pre-treatment of the biomass in order to make it more susceptible to biodegradation. Several studies have focused on enhancing the digestibility of lignocellulosic biomass through physical, chemical, biological and hybrid pre-treatments. It is known that higher temperature and acidic conditions stimulate cellulose and hemicellulose hydrolysis followed by the formation and release of a range of low molecular mass compounds. ${ }^{10}$ Similar effect was reported using alkali and certain enzymes. ${ }^{11}$

The production of biogas from BSG by anaerobic fermentation can be efficient only if the hydrolytic and methanogenic steps are separated ${ }^{12}$. The hydrolysis of the fibre material in the BSG is hindered by the presence of lignin and it is at the same time a potential limiting step for the complete degradation of the substrate. Microbial hydrolysis of the lignocellulose generates weak acids, furan derivatives and phenolic substances which might inhibit the subsequent microbial degradation steps - acidogenesis, acetogenesis and methanogenesis. The last step is especially sensitive, which makes the biogas production from lignocellulosic monosubstrates very difficult. Research on anaerobic digestion of BSG is therefore rather scarce. Older papers have shown that conventional digestion was not an economic option ${ }^{12,13}$ and have pointed out that in order to successfully digest the BSG, the hydrolysis stage of the anaerobic digestion process has to be separated from consequent stages, because it is the limiting step. Behmel et al. have also shown that the separated hydrolysis stage can provide as much as $85 \%$ degradation efficiency in overall process. ${ }^{13}$ However, these processes have never been applied, mostly due to high parasitic energy demands of hydrolysis and/or economic unfeasibility (low energy prices at the time).

Solid-state anaerobic digestion (SS-AD), namely an anaerobic digestion system that operates at a total solids (TS) content higher than $15 \%$, is a promising technology for converting the lignocellulosic biomass to renewable energy in the form of biogas. ${ }^{14}$ The SS-AD is considered to be more suitable for the treatment of lignocellulosic biomass than conventional $\mathrm{AD}$ due to the reduced floating and stratification problems associated with fibrous materials. ${ }^{15,16}$ Furthermore, the SS-AD has several other advantages compared to conventional anaerobic digestion: smaller reactor volume, lower energy requirements for heating, minimal material handling requirements, and lower total energy demand for process operation. ${ }^{16}$ The biogas production from SS-AD is comparable to the output of conventional $\mathrm{AD},{ }^{17}$ however it performs more effectively at higher organic loading rates and has higher volumetric biogas productivity. ${ }^{18}$

In this work the biodegradability of raw and pretreated BSG was examined. First, the biogas potential of the BSG was determined. Subsequently, the biodegradability of the BSG was determined using two distinct types of
SS-AD systems, a single-stage SS-AD with recycling of the percolating leachate liquid, and a two-stage SS-AD, where the SS-AD reactor was coupled with a granular biomass reactor (GBR) treating the percolating leachate. The goal was to determine the real potential of biogas production from the BSG in SS-AD systems.

\section{Experimental}

\section{1. Substrates}

The brewery spent grain (BSG) and the anaerobically treated brewery wastewater (BWW) were collected from a local brewery with the annual BSG production of 17,000 tonnes and the brewery wastewater production of approx. $400,000 \mathrm{~m}^{3}$ per year. This wastewater is treated in the EGSB reactor, BWW was collected from the effluent. The BSG is a solid material with granular structure of $2-4 \mathrm{~mm}$ in size and had a total solids (TS) concentration between 200 and $300 \mathrm{~g} \mathrm{~kg}^{-1}$. Of those, on average, $95 \%$ were volatile solids (VS). TOC was in range of $65-70 \%$ of TS. To ensure adequate hydraulic handling during pre-treatment, the BWW was used in the BSG:BWW mixture with a ratio of $1: 2$. The BWW had TOC in the range of $100-120 \mathrm{mg} \mathrm{L}^{-1}$, which was negligible compared to the amount of TOC from the BSG in the BSG-BWW mixture.

\section{2. Inoculum}

The seed inoculum was taken from an operational EGSB (Expanded Granular Sludge Bed) reactor of the same brewery where the substrates were collected. The sludge was typically granular with the TS concentration of 50 to $80 \mathrm{~g} \mathrm{~L}^{-1}$, of which $85 \%$ were VS.

\section{3. The Biogas Potential Assay}

The assay was performed in $500 \mathrm{ml}$ WTW OxiTop ${ }^{\circledR}$ serum bottles which were filled with inoculum and substrate. The inoculum was pre-incubated for seven days at $37^{\circ} \mathrm{C}$. The test mixture containing $100 \mathrm{~mL}$ of inoculum, $20 \mathrm{~mL}$ of buffer $\left(\mathrm{KH}_{2} \mathrm{PO}_{4}\right.$ and $\left.\mathrm{NaHPO}_{4}\right)$ to maintain the p$\mathrm{H}$-value between 7.3 and 7.5, the grinded substrate (BSG+BWW) and deoxygenized water to $500 \mathrm{~mL}$. The biogas production was monitored by measuring the pressure difference in the bottles with a digital control module. The planned duration of the assay was standard 21 days; however the assay was stopped after 14 days due to the completion of the process. Three substrates were tested: (i) raw BSG and thermo-chemically pre-treated BSG acidified with $\mathrm{HCl}$ (pH-value 2.0) at (ii) $70{ }^{\circ} \mathrm{C}$ and (iii) $140{ }^{\circ} \mathrm{C}$ for two hours. The organic load was (i) $164.6 \mathrm{mg}$, (ii) $164.5 \mathrm{mg}$ and (iii) $164.4 \mathrm{mg}$ of BSG per bottle, respectively (every bottle approx. $350 \mathrm{mg}$ of mixture $\mathrm{BSG}+\mathrm{BWW}$ ). The whole procedure has been performed according to guidelines presented in Angelidaki et al. ${ }^{19}$ 


\section{4. Pre-treatment}

Chemical and thermal pre-treatments are widely recognised as possible hydrolysis treatments for lignocellulosic materials such as BSG. ${ }^{10}$ In this work, alkaline $(50 \%$ $\mathrm{NaOH})$ and acid $(30 \% \mathrm{HCl})$ thermo-chemical hydrolyses were used. This selection was based on the fact that those two chemicals are readily available in the brewery. They are used in the brewing process and a possible implementation of the pre-treatment of BSG would cause minimum expenses. The acid was added to the BSG:BWW mixture to achieve $\mathrm{pH}<2.0$, while the alkali was used to achieve $\mathrm{p}$ $\mathrm{H}>13$.0. Several experiments were conducted at different temperatures (ranging from $20^{\circ} \mathrm{C}$ to $160^{\circ} \mathrm{C}$ ) and a detention time of 2 hours. After treatment, the liquid and solid phase were separated using a $0.25 \mathrm{~mm}$ sieve (similar to the separation of grains and brew malt in the brewing process) followed by a 10 bar press. The efficiency of hydrolysis was evaluated by TOC extraction from solid to liquid phase. The most feasible option was then used in further experiments.

\section{5. Experimental Setup of SS-AD}

Two reactor configurations were used (Figure 1). The single-stage SS-AD reactor (Armfield, UK) setup consisted of a $5 \mathrm{~L}$ reactor vessel and a peristaltic pump (Watson-Marlow, UK), used to recirculate the leachate which percolated the BSG/inoculum pile in the reactor. 1 $\mathrm{kg}$ of BSG (either raw or pre-treated) and $1 \mathrm{~L}$ of inoculum was mixed and inserted into the reactor, which gave an active reactor volume of approx. $3 \mathrm{~L}$. To fill the piping and percolate the $\mathrm{BSG}$ /inoculum pile, $2 \mathrm{~L}$ of $\mathrm{BWW}$ were used. In the case of the pre-treated BSG, the liquid from the pre-

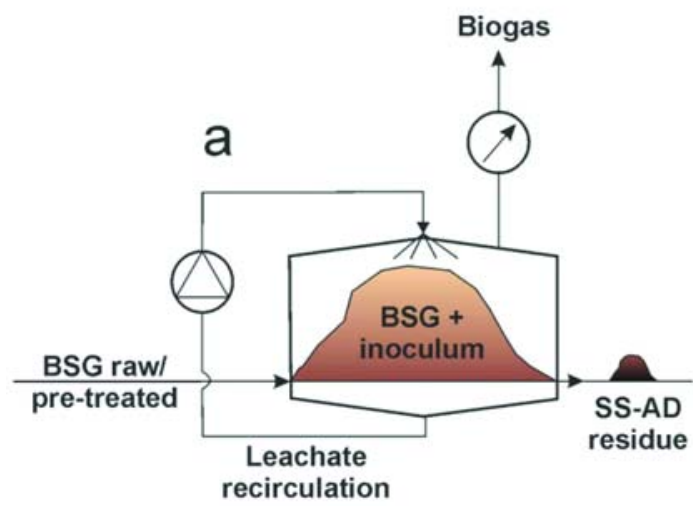

treatment was used as a part of the before mentioned $2 \mathrm{~L}$ of BWW. The targeted substrate to inoculum (S/I) ratio was approx. 4:1 in terms of total solids (TS).

The two-stage reactor setup consisted of a 5 L SS$\mathrm{AD}$ unit and a $5 \mathrm{~L}$ granulated biomass reactor unit (GBR) (Armfield, UK). The leachate rich in organic matter from the SS-AD reactor was pumped (Watson-Marlow, UK) into the GBR where it was additionally biodegraded. The effluent from the GBR was then used to percolate the BSG pile in the SS-AD reactor. In this way, the effluent was enriched with microorganisms from the GBR and inoculated the SS-AD stage. $1.5 \mathrm{~kg}$ of BSG (either raw or hydrolysed) was inserted into the SS-AD and $2 \mathrm{~L}$ of inoculum mixed with $1 \mathrm{~L}$ of BWW was used in the GBR. This gave an active reactor volume of $3 \mathrm{~L}$ in the GBR and approx. $2.5 \mathrm{~L}$ of active reactor volume in the SS-AD reactor. To fill the piping and percolate the BSG pile in the SS$\mathrm{AD}$ reactor, $3 \mathrm{~L}$ of $\mathrm{BWW}$ were used. In the case of the pre-treated BSG, the liquid from the pre-treatment was used as a part of the $3 \mathrm{~L}$ of BWW. The targeted S/I ratio was again approx. 4:1 in terms of TS.

The quantity of produced biogas was measured daily, and the composition of the biogas was determined every two days. The biogas quantity in this paper is generally presented in $\mathrm{L} \mathrm{kg}^{-1}$ of wet BSG, unless specificly stated in $\mathrm{L} \mathrm{kg}^{-1}$ vs. The $\mathrm{pH}$, total organic carbon (TOC) and total nitrogen $(\mathrm{TN})$ of the reactor leachate were also analysed every two days in order to assess the process. In the case of the two-stage configuration, the leachate from the SS-AD reactor and the effluent from the GBR were analysed. The biodegradation efficiency was determined by weighing the SS-AD residue, determining its total solids (TS) and comparing it to the initial TS quantity of raw BSG. In the case of one stage process, inoculum quantity

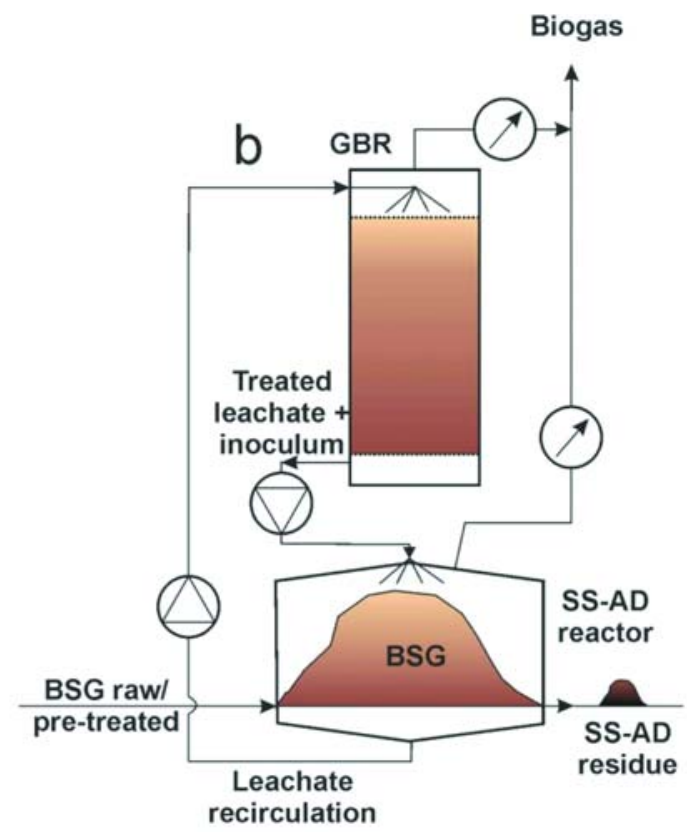

Figure 1. Experimental setup: a) single-stage; b) two-stage configuration of anaerobic bioreactor 
was subtracted from the efficiency calculation using the assumption that the quantity of inoculum was equal before and after the process.

\section{6. Analytical Methods}

The total organic carbon (TOC) was determined using the Total Organic Carbon Analyser (TOC-L CPH/CPN SSM-5000A, Shimadzu, Japan) according to HRN EN 1484:2002 ${ }^{20}$ for wastewater samples and for the solid BSG samples according to HRN EN 13137:2005. ${ }^{21}$ For the TOC analysis, the sample of wastewater was first acidified with $2 \mathrm{M} \mathrm{HCl}$ to obtain $\mathrm{pH}$-value below 2, and then diluted and acidified again if needed. The purpose of the acidification was the elimination of inorganic carbon in the form of $\mathrm{CO}_{2}$.

The total solids (TS) and volatile solids (VS) were determined according to the standard method HRN EN 12880:2005. ${ }^{22}$

Total nitrogen (TN) was measured using the Total Nitrogen Unit TNM-L on the Total Organic Carbon Analyser (TOC-L CPH/CPN, Shimadzu, Japan) according to HRN EN 12260:2008. ${ }^{23}$

The biogas composition $\left(\mathrm{CH}_{4}, \mathrm{CO}_{2}, \mathrm{H}_{2}, \mathrm{~N}_{2}, \mathrm{O}_{2}\right.$, $\mathrm{H}_{2} \mathrm{~S}$ ) was determined according to the in house developed method UTOO-02-100, using gas chromatography (Agilent 7890 A GC System, USA) equipped with two TCD detectors. High-purity helium (Messer Croatia Plin, Croatia, purity level 5.0) with flowrate of $20.00 \mathrm{~mL} \mathrm{~min}{ }^{-1}$ was used as a gas carrier. The composition of the biogas was expressed in normalized volume percentage.

The $\mathrm{pH}$-value was measured with the WTW $\mathrm{pH}$ electrode (WTW, Weilheim, Germany).

\section{Results and Discussion}

\section{1. Pre-treatment of BSG}

The BSG was mixed with BWW in the ratio of $1: 2$ to achieve adequate hydraulic handling. The TOC extraction from solid to liquid phase was $15.2 \%$, when the mixture was separated to solid and liquid part without any pre-treatment. The quantity of the solid phase before and after treatment was equal (approx. 33\%), which showed that the dewaterability of the mixture did not change significantly. The objective was to increase this extraction using the alkali $(\mathrm{NaOH})$ or acid $(\mathrm{HCl})$ readily available in the brewery. Therefore, $20 \mathrm{~mL}$ of alkali or acid per $\mathrm{kg}$ of BSG was added to achieve the required $\mathrm{pH}$-value and the BSG-BWW mixture was then thermally treated at different temperatures and at a detention time of 2 hours. Table 1 shows the results of the pre-treatment. The maximum TOC extraction $(55 \%)$ was obtained with acid pre-treatment at $140{ }^{\circ} \mathrm{C}$. The results clearly showed that the acid pre-treatment had greater effect than the alkali pre-treatment. It offered higher TOC extraction as well as better dewaterability of the BSG-BWW mixture. Although the solid phase quantity was considerably lower compared to the quantity before the pre-treatment (reduction from $33 \%$ to approx. 13\%), the TS concentration was much higher: from the initial TS BSG concentration of $230 \mathrm{~g} \mathrm{~kg}^{-1}$ to the final TS BSG concentration of $360-380 \mathrm{~g} \mathrm{~kg}^{-1}$. As a result, the increasing dewaterability did not considerably increase the TOC extraction, it just reduced the solid phase quantity (with increased TS concentration). Even at prolonged durations of the pre-treatment has not resulted in higher extraction (results not shown). Therefore, it was concluded that a maximum TOC extraction of $55 \%$ is achievable with this method of pre-treatment.

After the results from the pre-treatment experiments were obtained, the biogas potential assay was conducted. Raw and pre-treated BSG at $140{ }^{\circ} \mathrm{C}$ and $70{ }^{\circ} \mathrm{C}$ were used in the assay. The pre-treatment of BSG at $140{ }^{\circ} \mathrm{C}$ was used because of the highest efficiency comparing to the pretreatment at lower temperatures, while the pre-treatment at $70{ }^{\circ} \mathrm{C}$ was used because it was the pre-treatment process at the lowest temperature (minimum energy requirements) at which reasonably good results were obtained.

\section{2. The Biogas Potential}

Figure 2 shows a maximum obtained biogas potential of $120 \mathrm{~L} \mathrm{~kg}^{-1}$ of BSG. The actual rate of biogas production was similar in all cases. However, a higher biogas

Table 1. Results of different pre-treatment methods of BSG-BWW mixture

\begin{tabular}{ccccc}
\hline $\begin{array}{c}\text { Process } \\
\text { temperature }\left({ }^{\circ} \mathbf{C}\right)\end{array}$ & $\begin{array}{c}\text { Alkali pre-treatment } \\
\text { TOC extraction }\end{array}$ & $\begin{array}{c}\text { Dewaterability } \\
(\boldsymbol{\%} \text { of solid phase) }\end{array}$ & $\begin{array}{c}\text { Acid pre-treatment } \\
\text { TOC Extraction } \\
(\boldsymbol{\%})\end{array}$ & $\begin{array}{c}\text { Dewaterability } \\
(\boldsymbol{\%} \text { of solid phase })\end{array}$ \\
\hline $20^{*}$ & 25.7 & 25.5 & 21.0 & 29.2 \\
70 & 26.9 & 24.8 & 43.4 & 15.9 \\
95 & 27.2 & 24.5 & 46.1 & 15.7 \\
120 & 27.2 & 23.6 & 53.7 & 13.4 \\
140 & 36.5 & 23.4 & 55.0 & 12.3 \\
160 & 45.6 & 26.9 & 51.4 & 12.9 \\
\hline
\end{tabular}

*detention time in this case was 24 hours 
potential from acid pre-treated BSG, 115 and $120 \mathrm{~L} \mathrm{~kg}^{-1}$ of BSG at $70{ }^{\circ} \mathrm{C}$ and $140{ }^{\circ} \mathrm{C}$, respectively (with the average methane concentrations of $66 \%$ for both) can be observed, compared to the untreated raw BSG where the obtained biogas potential was only $105 \mathrm{~L} \mathrm{~kg}^{-1}$ of BSG. This was expected due to the efficient thermo-chemical hydrolysis of the BSG. The average methane concentration produced from raw BSG was $62 \%$. In our opinion, the similar biogas production rates obtained during the first 48 hours of the experiment originate from the fact that in the WTW OxiTop® assay a rather small quantity of substrate was used (up to $350 \mathrm{mg}$ with S/I ratio of 0.07), and therefore the difference was hardly distinguishable and the biogas production rates were unrealistic for actual biogas production. A larger quantity of the substrate was necessary to determine the biogas production rate more accurately which was performed by further SS-AD experimentation. Nevertheless, the BMP assay predicted the biogas potential at a sufficiently accurate level, which gave an orientation value for the biogas produced from the BSG.

\section{3. The Single-stage SS-AD}

The results of the biodegradation of BSG in a single-stage SS-AD are shown in Figure 3. The raw and pretreated BSG $\left(\mathrm{HCl}, 70{ }^{\circ} \mathrm{C}\right)$, biodegradation experiments were conducted simultaneously. In both reactors, $1 \mathrm{~kg}$ of BSG at concentration of $241 \mathrm{~g} \mathrm{~kg}^{-1}$ and $1 \mathrm{~L}$ of inoculum at concentration of $58.4 \mathrm{~g} \mathrm{~L}^{-1}$ were inserted into the reactors, which constituted an S/I ratio of 4.13. The results show that there was only a minor difference between the experiments. The biodegradation efficiency was $62.0 \%$ and
$62.2 \%$ on TS basis from raw and pre-treated BSG, respectively. The produced biogas was $87.4 \mathrm{~L} \mathrm{~kg}^{-1}$ and $89.1 \mathrm{~L}$ $\mathrm{kg}^{-1}$ for raw and pre-treated BSG, respectively. Furthermore, in terms of VS, the average biogas production was $386 \mathrm{~L} \mathrm{~kg}^{-1}$ vs and $389 \mathrm{~L} \mathrm{~kg}^{-1}$ vs . The methane concentrations were $59.4 \%$ and $62.1 \%$ for raw and pre-treated BSG, respectively. Consequently, the methane production was 51.9 $\mathrm{L} \mathrm{kg}^{-1}$ and $55.3 \mathrm{~L} \mathrm{~kg}^{-1}$ for raw and pre-treated BSG, respectively, which shows a slightly better methane production $(6.5 \%)$ from the pre-treated BSG. The initial TOC of the leachate from the raw BSG was $89.7 \mathrm{mg} \mathrm{L}^{-1}$. The TOC increased to a maximum of $1,129 \mathrm{mg} \mathrm{L}^{-1}$ during the experiment, and decreased to $628 \mathrm{mg} \mathrm{L}^{-1}$ at the end of the experiment. The initial TOC from the pre-treated BSG was much higher $\left(2,221 \mathrm{mg} \mathrm{L}^{-1}\right)$ due to the solid-liquid extraction. After approx. 8 days, the TOC concentration was similar to the TOC from the raw BSG. The $\mathrm{pH}$-value was similar in both cases, approx. 6.7 at the beginning, and 7.8 and 7.6 at the end of the experiment, with the maximum at 8.3 and 8.2 from raw and pre-treated BSG, respectively. These values were within the expected range. The average volume methane productivity was $0.57 \mathrm{~L}$ per $\mathrm{L}$ of active reactor volume per day $\left(\mathrm{L} \mathrm{L}^{-1} \mathrm{day}^{-1}\right)$ and $0.61 \mathrm{~L} \mathrm{~L}^{-1} \mathrm{day}^{-1}$ from raw and pre-treated BSG, respectively. The maximum daily methane yields were $4.36 \mathrm{~L} \mathrm{~kg}^{-1}$ day $^{-1}$ (19.04 $\mathrm{L} \mathrm{kg}^{-1}$ day $^{-1}$ ) and $5.32 \mathrm{~L} \mathrm{~kg}^{-1}$ day $^{-1}\left(23.2 \mathrm{~L} \mathrm{~kg}^{-1}{ }_{\mathrm{vs}}\right.$ day $\left.^{-1}\right)$ from raw and pre-treated BSG, respectively. These values were somewhat higher than other reports show for the SS$\mathrm{AD}$ of lignocellulosic substrates. Brown et al. reports maximum values of approx. $12.5 \mathrm{~L} \mathrm{~kg}^{-1}$ vs day $^{-1}$ for wheat straw, whereas Liew et al. reports a similar value of approx. $12.0 \mathrm{~L} \mathrm{~kg}^{-1} \mathrm{vay}^{-1}$ for wheat straw as well. ${ }^{17,24}$ This comparisons show that the BSG is a good lignocellulosic

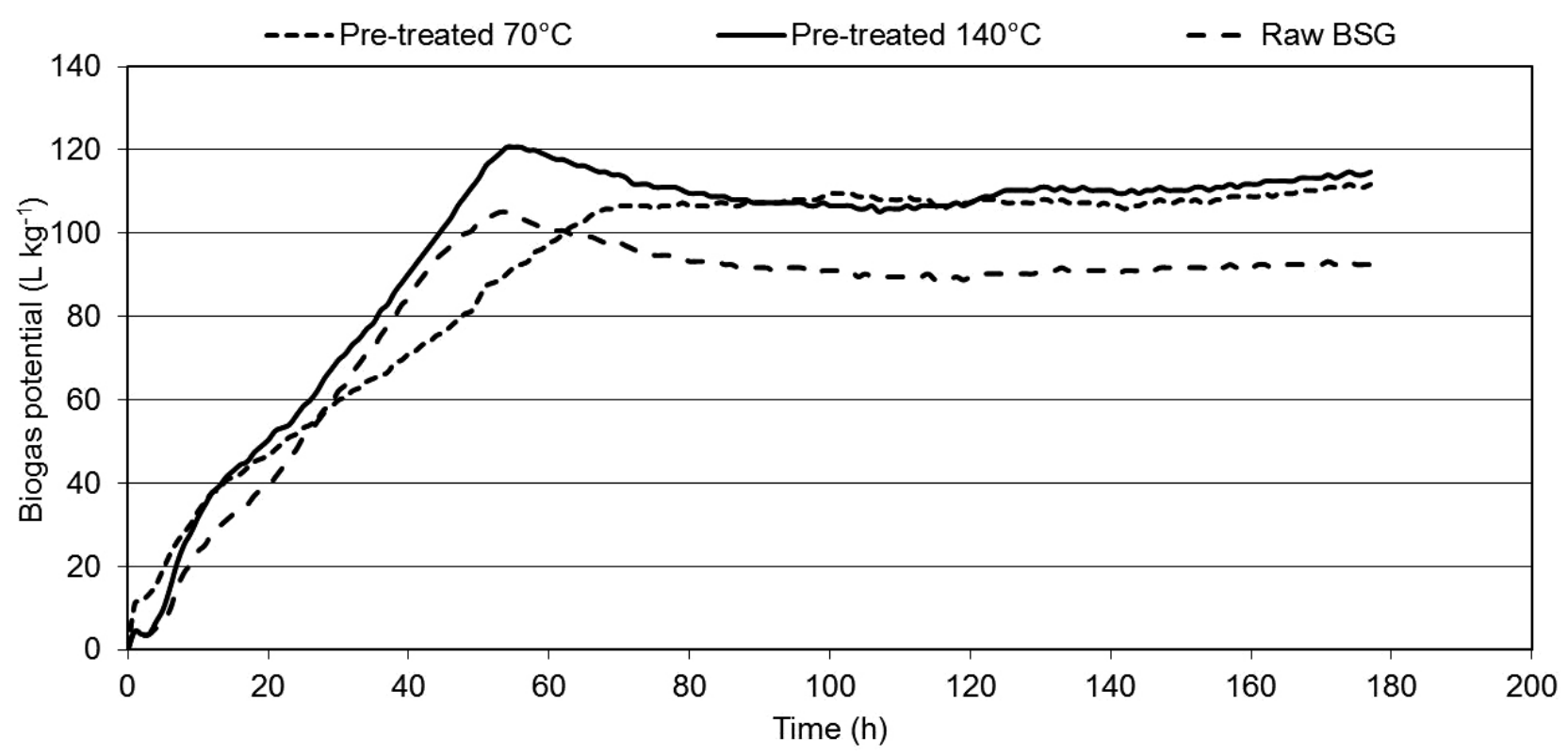

Figure 2. Biogas production during Biogas potential assay with BSG 
substrate for methane production. It also shows that the single-stage SS-AD process operates within expected pa-
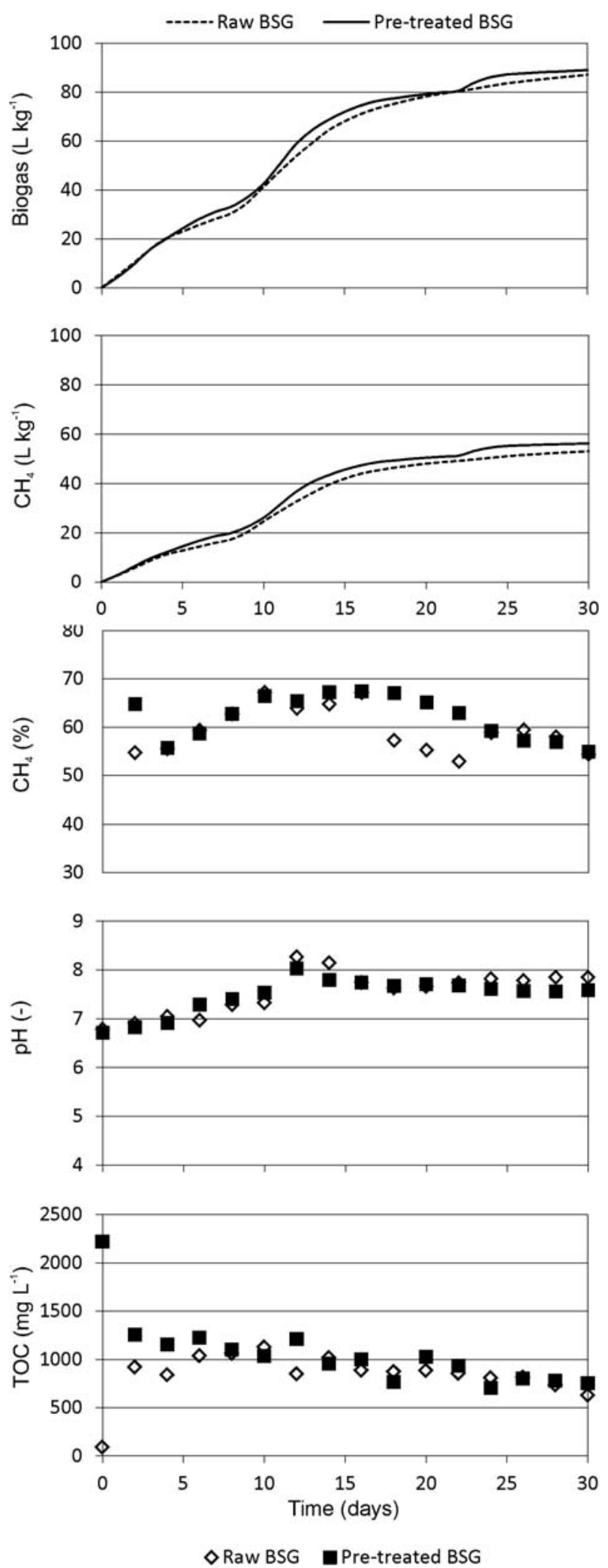

Figure 3. Single-stage SS-AD results rameters, although it has achieved only $75 \%$ of the biogas potential ( $70 \%$ methane potential).

\section{4. Two-stage SS-AD}

The BSG biodegradation results in a two-stage SS$\mathrm{AD}$ are shown in Figure 4 and Figure 5. In both cases, the raw and the pre-treated $\mathrm{BSG}\left(\mathrm{HCl}, 70{ }^{\circ} \mathrm{C}\right), 1.5 \mathrm{~kg}$ of $\mathrm{BSG}$ at concentration of $243 \mathrm{~g} \mathrm{~kg}^{-1}$ and $2 \mathrm{~L}$ of inoculum at concentration of $50.1 \mathrm{~g} \mathrm{~L}^{-1}$ were inserted into the SS-AD and GBR reactors, respectively. That constituted the $\mathrm{S} / \mathrm{I}$ ratio of 3.64. In the case of the two-stage SS-AD the experiment with the pre-treated BSG showed better results. The total produced biogas was $89.1 \mathrm{~L} \mathrm{~kg}^{-1}$ and $103.2 \mathrm{~L} \mathrm{~kg}^{-1}$ from raw and pre-treated BSG, respectively (Figure 4). Furthermore, in terms of VS, the average biogas production was $386 \mathrm{~L} \mathrm{~kg}^{-1}$ vs and $447 \mathrm{~L} \mathrm{~kg}^{-1}$. Analysing the results more closely, it can be shown that the GBR achieved a similar biogas production (Figure 4) of $67.0 \mathrm{~L} \mathrm{~kg}^{-1}$ and $65.3 \mathrm{~L} \mathrm{~kg}^{-1}$ from raw and pre-treated $\mathrm{BSG}$, respectively. The methane production in the GBR was $46.4 \mathrm{~L} \mathrm{~kg}^{-1}$ and $45.4 \mathrm{~L} \mathrm{~kg}^{-1}$ from raw and pre-treated BSG, respectively. The SS-AD reactor showed better biogas production using the pre-treated BSG with $37.9 \mathrm{~L} \mathrm{~kg}^{-1}$ compared to the raw BSG from which $22.1 \mathrm{~L} \mathrm{~kg}^{-1}$ of biogas was produced. Comparing the methane production however shows similar results with $12.3 \mathrm{~L} \mathrm{~kg}^{-1}$ for raw BSG and $13.3 \mathrm{~L} \mathrm{~kg}^{-1}$ for pre-treated BSG. Taking this into account, we can conclude that the total methane production (Figure 5) from both raw and pre-treated BSG is equal with $58.7 \mathrm{~L}$
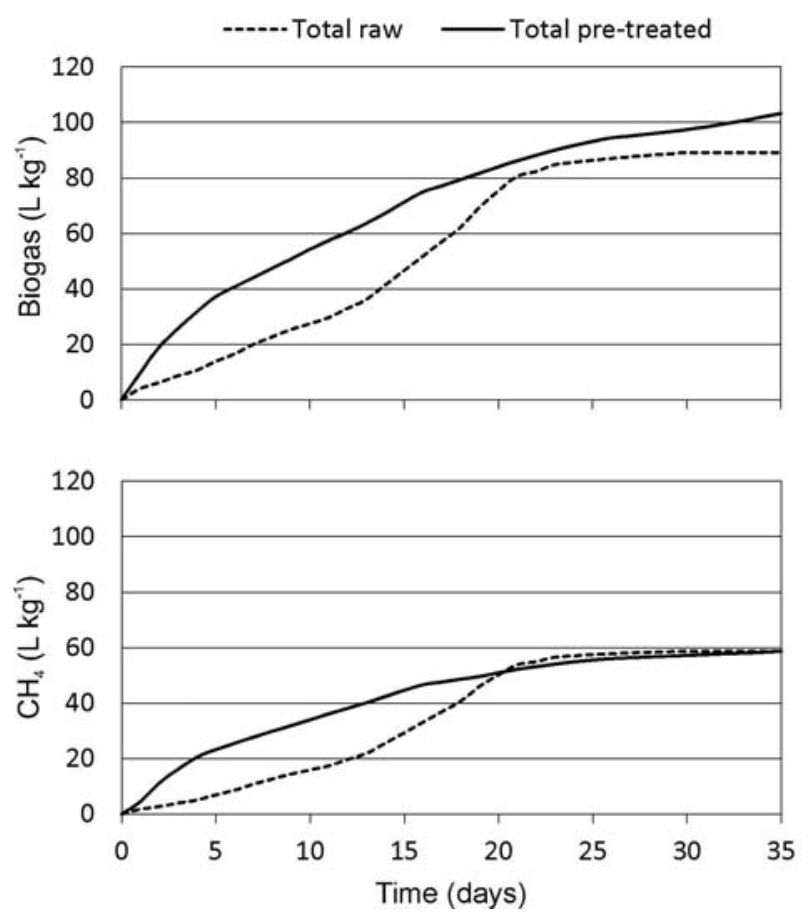

Figure 4. Total biogas and methane production in the two-stage process 

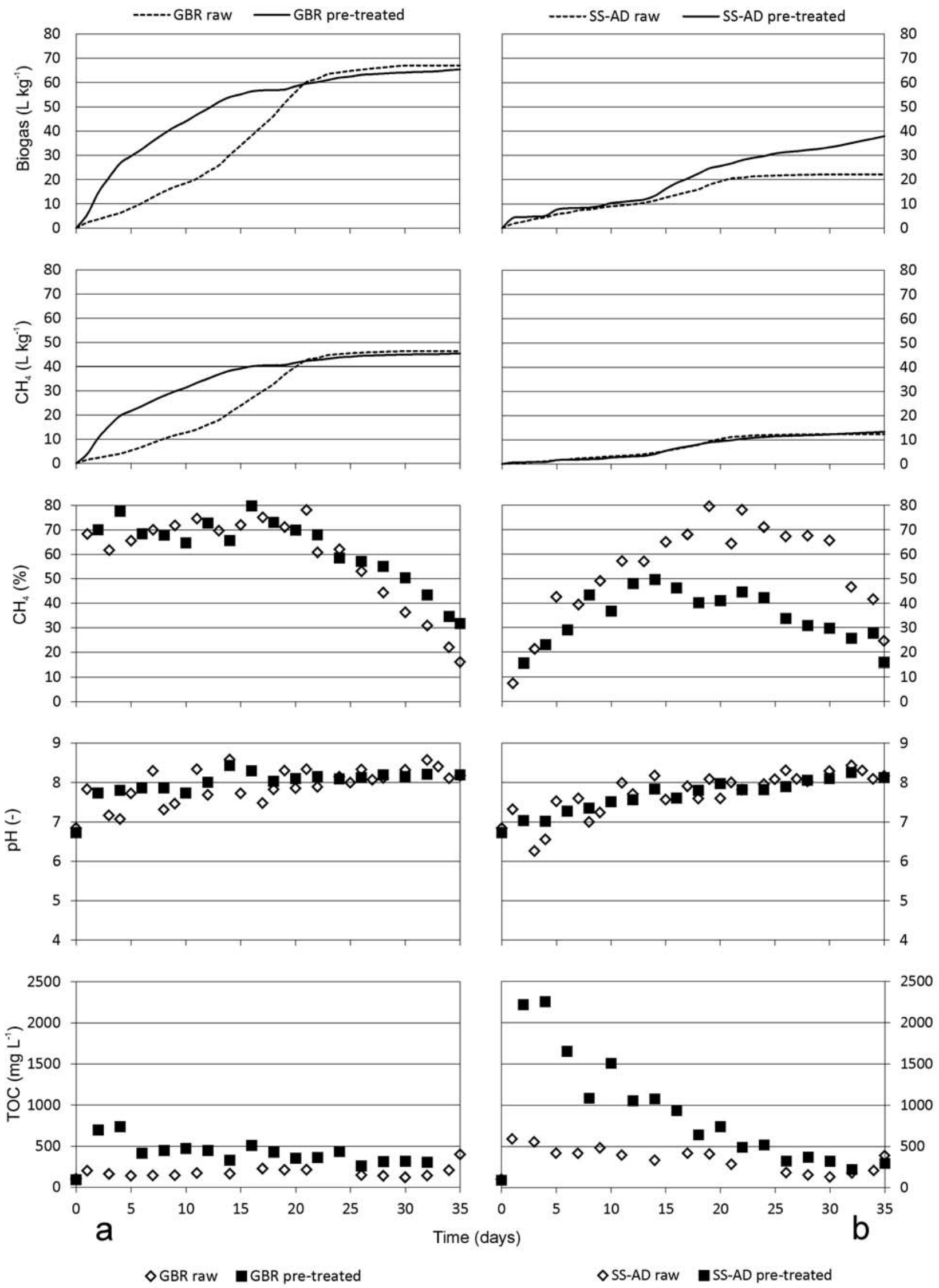

$\Delta$ GBR raw $\quad$ GBR pre-treated

$\triangle S S-A D$ raw $\quad$ SS-AD pre-treated

Figure 5. Two-stage SS-AD results: column a) Granular biomass reactor; b) SS-AD reactor 
$\mathrm{kg}^{-1}\left(254 \mathrm{~L} \mathrm{~kg}^{-1}{ }_{\mathrm{vs}}\right)$, and consequently the pre-treatment does not impact the methane production from BSG significantly. It can only be shown that the production rate was higher in the case of the pre-treated BSG - it simply degraded faster (Figure 4). This was also reflected in the TOC of the leachate. The pre-treated BSG achieved higher TOC values in the SS-AD reactor (over $2,000 \mathrm{mg} \mathrm{L}^{-1}$, whereas the maximum from the raw BSG was $590 \mathrm{mg} \mathrm{L}^{-1}$ - Figure 4) because of the pre-treatment and hence, it had higher biogas and methane production rates. The $\mathrm{pH}$-value of the SS-AD leachate was similar in both experiments, initially approx. 6.7, peaking at 8.4 and 8.3 from raw and pre-treated BSG, respectively. The $\mathrm{pH}$-value of the GBR effluent was also similar in both experiments, initially approx. 6.7, peaking at 8.6 and 8.4 from raw and pre-treated BSG, respectively. Taking into account the maximum daily methane yield (total methane), the raw BSG yielded $5.3 \mathrm{~L} \mathrm{~kg}^{-1}$ day $^{-1}\left(23.0 \mathrm{~L} \mathrm{~kg}^{-1}\right.$ day $\left.^{-1}\right)$, whereas the pre-treated BSG yielded $6.6 \mathrm{~L} \mathrm{~kg}^{-1}$ day $^{-1}(28.8 \mathrm{~L}$ $\mathrm{kg}^{-1}{ }_{\mathrm{vs}} \mathrm{day}^{-1}$ ). However, after 20 days of the cycle, there was not much difference. The process came more or less to a halt, when the TOC of the GBR and SS-AD reactor became equal. This was the case in both experiments at approx. day 25, when the TOC of the raw BSG leachate was approx. $160 \mathrm{mg} \mathrm{L}^{-1}$ and the TOC of the pre-treated BSG leachate was approx. $290 \mathrm{mg} \mathrm{L}^{-1}$ (Figure 4). Nevertheless, producing more $\mathrm{CO}_{2}$, does show on the biodegradability of the BSG. The raw BSG was degraded $63.5 \%$, while the pre-treated BSG was degraded $73.6 \%$ on TS basis. The two-stage produced slightly more methane (58.7 $\mathrm{L} \mathrm{kg}^{-1}$ versus $55.3 \mathrm{~L} \mathrm{~kg}^{-1}$ ) comparing to the single-stage system and had a higher maximum daily methane yield (28.8 $\mathrm{L} \mathrm{kg}^{-1}$ vs day $^{-1}$ versus $23.3 \mathrm{~L} \mathrm{~kg}^{-1}$ vs day $\left.^{-1}\right)$. The average volume methane productivity, the two-stage system produced $0.46 \mathrm{~L} \mathrm{~L}^{-1}$ day $^{-1}$, which was lower than in the one-stage system $\left(0.61 \mathrm{~L} \mathrm{~L}^{-1}\right.$ day $\left.^{-1}\right)$. However, the real comparison was at the time when the two-stage system achieved equal methane production as the single-stage (day 22), and in that case a comparable average volume methane productivity was $0.68 \mathrm{~L} \mathrm{~L}^{-1}$ day $^{-1}$. Therefore, it can be concluded that the two-stage system yielded more and degraded more efficiently than the single-stage system. It has also achieved $85 \%$ of biogas potential ( $74 \%$ of methane potential).

\section{5. Impact of the Results on BSG Biogas Production}

The results clearly showed that the SS-AD technology could be applied for the digestion of BSG with good results, achieving up to $73 \%$ degradation and a methane yield of up to $58.7 \mathrm{~L} \mathrm{~kg}^{-1}$ of BSG. This value yields up to $10 \mathrm{~L}$ of methane per $\mathrm{L}$ of produced brew and could replace up to $50 \%$ of the natural gas required for brew production. Combined with the methane from the brewery wastewater and surplus yeast this could add up to $75 \%$ of natu- ral gas replacement. ${ }^{6}$ By applying the presented process to the brewery production of 100 million $\mathrm{L}$ of brew (middle sized brewery - like the one from which the samples were collected) with 17,000 tonnes of BSG per year, the active reactor size would be approx. $4,300 \mathrm{~m}^{3}$ for the single-stage process and approx. $5,200 \mathrm{~m}^{3}$ for the two-stage process. The annual methane yield would be approx. 1 million $\mathrm{m}^{3}$. These sizes are comparable to the average biogas plants using energy crops.

Although the results are promising and comparable to what other researchers report on lignocellulosic substrates ${ }^{15-18,24}$ and the BSG is a good lignocellulosic substrate for biogas production, it is our opinion that further research is needed for full scale implementation of biogas production from the BSG with the SS-AD technology. Special emphasis should be addressed to possible inhibitors that could appear during the degradation of lignocellulose. Sežun et al. reported that $p$-cresol inhibition occurred after prolonged operation in a conventional $\mathrm{AD}$ of BSG. ${ }^{25}$ The granulated biomass does have the ability to successfully degrade phenolic compounds, ${ }^{26,27}$ therefore this problem can be overcome by using the two-stage SSAD system. Also, the TN concentration should be observed. Since the BSG is a protein rich substrate with TN concentration of approx. 11-13 $\mathrm{g} \mathrm{kg}^{-1}$, sufficient quantity of liquid (wastewater) for percolation should be present in order to lower the TN concentration below the inhibition limit. A minimum of 2:1 dilution should be applied to achieve concentration of maximum $4 \mathrm{~g} \mathrm{~L}^{-1}$ in the leachate to avoid inhibition concentration. ${ }^{28}$ In our case, we have taken that ratio into account when the wastewater has been added for percolation. It is in our opinion that a long term pilot-scale operation is necessary to confirm the BSG digestion to be feasible for industrial-scale application.

\section{Conclusions}

The anaerobic biodegradation of the BSG was studied utilizing a single-stage and a two-stage SS-AD. The biogas potential assay conducted on the OxiTop ${ }^{\circledR}$ showed that the biogas potential of the BSG was $120 \mathrm{~L} \mathrm{~kg}^{-1}$ (66\% methane) and that the research of the process of anaerobic digestion of BSG is justified, due to the potential environmental and economic benefits from the biogas production from the substrate which represents one of the main excess material streams from the brewing industry. In accordance with the obtained results, SS-AD is a promising option for biogas production from BSG. $85 \%$ of biogas potential and $74 \%$ of biomethane potential can be achieved. The two-stage SS-AD process was more efficient in comparison to the single-stage process in which $75 \%$ of biogas potential and $70 \%$ of methane potential was achieved. The research also showed that the pretreatment of the BSG had no effect on the total biogas yield in the single-stage process, while the two-stage pro- 
cess with the pre-treated BSG showed slightly better results. Further research should be carried out to develop a two-stage AD process which should ensure stable longterm biogas production which is one of the essential prerequisites before transferring the research of the BSG $\mathrm{AD}$ process to a higher scale. In addition, special attention should be addressed to the prevention of inhibition of the biogas production process which could occur from eventual intermediary compounds formed during the degradation of BSG.

\section{Acknowledgements}

This work was supported by HAMAG BICRO, Croatian Agency for SMEs, Innovations and Investments. The authors would like to thank the Slovenian beer industry for their cooperation during this research.

\section{References}

1. N. Ishiwaki, H. Murayama, H. Awayama, O. Kanauchi, T. Sati, MBAA Tech. Quarter. 2000, 37, No. 2, 261-265.

2. S. Connaughton, G. Collins, V. O'Flaherty, Water Res. 2006, 40, No. 13, 2503-2510.

http://dx.doi.org/10.1016/j.watres.2006.04.044

3. A. Alvarado-Lassman, E. Rustrián, M.A. García-Alvarado, G.C. Rodríguez-Jiménez, E. Houbron, Bioresour. Technol. 2008, 99, No. 8, 3009-3015.

http://dx.doi.org/10.1016/j.biortech.2007.06.022

4. M. I. Baloch, J. C. Akunna, P.J. Collier, Bioresour. Technol. 2007, 98, No. 9, 1849-1855.

http://dx.doi.org/10.1016/j.biortech.2006.06.014

5. K. Neira, D. Jeison, Water Sci. Technol. 2010, 61, 1129- 1135.

6. G. D. Zupančič, I. Škrjanec, R. Marinšek Logar, Bioresour. Technol. 2012, 124, 328-337.

http://dx.doi.org/10.1016/j.biortech.2012.08.064

http://dx.doi.org/10.2166/wst.2010.052

7. S. I. Mussatto, G. Dragone, I. C. Roberto, J. Cereal Sci. 2006, 43, 1-14.

http://dx.doi.org/10.1016/j.jcs.2005.06.001

8. J. Perez, J. M. Dorado, T. D. Rubia, J. Martinez, Int. Microbiol. 2002, 5, No. 2, 53-63.

http://dx.doi.org/10.1007/s10123-002-0062-3

9. J. J. Ko, Y. Shimizu, K. Ikeda, S. K. Kim, C. H. Park, S. Matsui, Bioresour. Technol. 2009, 100, No. 4, 1622-1627.

http://dx.doi.org/10.1016/j.biortech.2008.09.029

10. T. V. Fernandes, G. J. Klaasse Bos, G. Zeeman, J. P. M. San- ders, J. B. van Lier, Bioresour. Technol. 2009, 100, No. 9, 2575-2579.

http://dx.doi.org/10.1016/j.biortech.2008.12.012

11. C. H. Wang, W. B. Lu, J. S. Chang, Int. J. Hydrogen Energ. 2007, 32, No. 16, 3849-3859.

http://dx.doi.org/10.1016/j.ijhydene.2007.05.009

12. U. Behmel, G. Leupold, S. Vieweger, Chem. Mikrobiol. Technol. Lebensm. 1993, 15, No. 112, 55-61.

13. C. Rieker, M. Moeller, K. Sommer, Brauwelt 1992, 16-17, 716-721.

14. T. C. Sawatdeenarunat, K. C. Surendra, D. Takara, H. Oechsner, S. K. Khanal, Bioresour. Technol. 2015, 178, 178-186. http://dx.doi.org/10.1016/j.biortech.2014.09.103

15. O. P. Karthikeyan, C. Visvanathan, Rev. Env. Sci. Bio/Technol. 2013, 12, No. 3, 257-284.

http://dx.doi.org/10.1007/s11157-012-9304-9

16. Y. Li, S. Y. Park, J. Zhu, Renew. Sust. Energ. Rev. 2011, 15, No. $1,821-826$. http://dx.doi.org/10.1016/j.rser.2010.07.042

17. D. Brown, J. Shi, Y. Li, Bioresour. Technol. 2012, 124, 379386. http://dx.doi.org/10.1016/j.biortech.2012.08.051

18. L. Yang, F. Xu, X. Ge, Y. Li, Renew. Sust. Energ. Rev. 2015 , 44, 824-834. http://dx.doi.org/10.1016/j.rser.2015.01.002

19. I. Angelidaki, M. Alves, D. Bolzonella, L. Borzacconi, J.L. Campos, A.J. Guwy, S. Kalyuzhnyi, P. Jenicek, J.B. van Lier, Water Sci. Technol. 2009, 59, No. 5, 927-934. http://dx.doi.org/10.2166/wst.2009.040

20. HRN EN 1484:2002; Water analysis - Guidelines for the determination of total organic carbon (TOC) and dissolved organic carbon (DOC) (EN 1484:1997).

21. HRN EN 13137:2005; Characterization of waste - Determination of total organic carbon (TOC) in waste, sludges and sediments (EN 13137:2001).

22. HRN EN 12880:2005; Characterization of sludges - Determination of dry residue and water content (EN 12880:2000).

23. HRN EN 12260:2008; Water quality - Determination of nitrogen - Determination of bound nitrogen ( $\mathrm{TNb}$ ), following oxidation to nitrogen oxides (EN 12260:2003).

24. L. N. Liew, J. Shi, Y. Li, Biomass Bioenergy 2012, 46, 125 132. http://dx.doi.org/10.1016/j.biombioe.2012.09.014

25. M. Sežun, V. Grilc, G. D. Zupančič, R. Marinšek-Logar, Acta Chim. Slov. 2011, 58, No. 1, 158-166.

26. S. J. B. Duff, K. J. Kennedy, A. J. Brady, Water Res. 1995, 29, No. 2, 645-651. http://dx.doi.org/10.1016/0043-1354(94)00160-9

27. C. Scully, G. Collins, V. O'Flaherty, Water Sci. Technol. 2007, 55, No. 1-2, 43-51. http://dx.doi.org/10.2166/wst.2007.027

28. S. Sung, T. Liu, Chemosphere 2003, 53, No. 1, 43-52. http://dx.doi.org/10.1016/S0045-6535(03)00434-X 


\section{Povzetek}

Odpadne pivovarske tropine (BSG) količinsko predstavljajo približno 85\% vseh stranskih proizvodov pivovarske industrije. Številne študije v zadnjih letih se ukvarjajo z raziskavami proizvodnje bioplina iz BSG, kar vzpodbuja velika poraba energije v pivovarstvu in hkrati naraščajoče cene energentov. Ta raziskava obravnava biorazgradljivost surovega in predhodno obdelanega BSG v enostopenjskem in dvostopenjskem procesu anaerobne fermentacije v trdnem stanju (SSAD). Rezultati so pokazali, da ima BSG bioplinski potencial $120 \mathrm{~L} / \mathrm{kg}$ tropin. V enostopenjskem sistemu anaerobne fermentacije je bila proizvodnja bioplina iz neobdelanega BSG $(87,4 \mathrm{~L} / \mathrm{kg})$ skoraj enaka proizvodnji bioplina iz obdelanega BSG $(89,1 \mathrm{~L} / \mathrm{kg})$, medtem ko je bila proizvodnja metana v prvem primeru 51,9 in v drugem primeru $55,3 \mathrm{~L} / \mathrm{kg}$, biorazgradljivost pa $62,0 \%$ za neobdelan BSG in $62,2 \%$ za obdelan BSG. Z dvostopenjskim sistemom SS-AD so bili doseženi boljši rezultati proizvodnje bioplina za predobdelan BSG z bioplinskim donosom 103,2 L/kg in biorazgradljivostjo 73,6\%, donos bioplina iz neobdelanega BSG je bil 89,1 L/kg in biorazgradljivost 63,5\%. V dvostopenjskem procesu je bil donos metana enak pri obdelanem in neobdelanem BSG $(58,7 \mathrm{~L} / \mathrm{kg})$. 